\title{
ОСИСТЕМНЫЙ ХАРАКТЕР ПРОБЛЕМЫ ОБМАНУТЫХ ДОЛЬЩИКОВ В РОССИИ
}

\begin{abstract}
АннотАция. Дана характеристика основных изменений в механизме финансирования строительства жилья, введённых в действие с 1 июля 2017 г. и запланированных на 2018 г. Поставлен вопрос: как оценивать их содержание и достаточность для решения накопившихся проблем в отрасли строительства и ликвидации обманутых дольщиков. Сформулировано предположение, что проблема долевого строительства масштабнее, чем это принято считать, а поставленная цель изменений её сужает. Предложено использование системо-мыследеятельностной методологии, адаптированной к целям исследования. Показано, что формулировка проблемы, которую нужно решать, - это результат пошагового движения от анализа ситуации затруднения к определению целей, достижение которых должно привести к изменению ситуации и снять затруднения; затем $\kappa$ определению объектов (сил, вызвавших ситуацию затруднения и нуждающихся в перепроектировании). Описана логика движения по схеме выявления проблемы и оценки деятельности по её преодолению, сделан вывод о необходимости проекта системного совершенствования деятельности всех сторон, участвующих в процессе создания объектов недвижимости и влияющих на него - государства и контролирующих застройщиков инстанций, Центрального Банка и коммерческих кредитных организаций, страховщиков и поставщиков ресурсов. Предложена и обоснована авторская формулировка проблемы, решение которой необходимо для снятия ситуации затруднения. Рассмотрено финансирование строительства жилья за рубежом. Подтверждён системный характер проблемы, необходимость создания общехозяйственных и отраслевых предпосылок для её решения и изменения институционального устройства рынка в течение переходного периода, без которых проектное финансирование невозможно.

кЛЮчЕВЫЕ СЛОВА. Обманутые дольщики; организации-застройщики; проектное финансирование; системо-мыследеятельностная методология.

ИНФОРМАЦИЯ О СТАТЬЕ. Дата поступления 30 октября 2017 г.; дата принятия к печати 19 декабря 2017 г.; дата онлайн-размещения 29 декабря 2017 г.
\end{abstract}

T. V. Svetnik

Baikal State University,

Irkutsk, Russian Federation

\section{DETERMINATION OF THE MOST EFFECTIVE INNOVATIONS IN THE FIELD OF HOUSING CONSTRUCTION}

\begin{abstract}
The article shows characteristic of the main changes in a mechanism financing the housing construction that have been put into effect from July 1, 2017 and planned for 2018. The question is raised: how to assess their content and sufficiency for solving the accumulated problems in the construction sector and liquidating the problem of hoodwinked investors. The author assumes that the problem of the shared construction is larger than it is commonly believed, and the desired goal of the changes makes it more narrow. The article offers to use the systematic mental-action methodology adapted to objectives of the study. The article shows that statement of the problem to be solved is the result of a step-by-step movement from the analysis of the situation of difficulty to the definition of goals, the achievement of which should lead to a change in the situation and remove difficulties; then it moves to the definition of objects (forces that cause a situation of difficulty and that need a
\end{abstract}

\section{Baikal Research Journal}


redesign). The article describes the logic of movement by the scheme of identifying the problem and assessing the activities to overcome it and makes a conclusion on a necessity to systematically improve the activities of all parties involved in the process of building real estate objects and influencing it - the government and controlling developers of institutions, the Central Bank and commercial credit organizations, insurers and resource providers. The article offers and substantiates the author's problem statement, the solution of which is necessary to remove the situation of difficulty. It considers financing of the housing construction abroad. The article confirms the systemic nature of the problem, the necessity to create general economic and sectorial prerequisites for its solution and to change the institutional structure of the market during the transition period, without which the project financing is impossible.

KEYWORDS. Hoodwinked investors; organizations-developers; project financing; systematic mental-action methodology.

ARTICLE INFO. Received October 30, 2017; accepted December 19, 2017; available online December 29, 2017.

Необходимость изменений в сфере долевого строительства. Реакцией на накопившиеся проблемы отрасли строительства, активно обсуждаемые учёными и практиками, стали кардинальные изменения условий деятельности организаций-застройщиков жилья и иных объектов недвижимости. Цель изменений многократно озвучивалась, например, в формулировке генерального директора Агентства ипотечного жилищного кредитования (АИЖКК) А. Плутника она сформулирована следующим образом: создать действенный механизм защиты прав граждан, который сведет к минимуму риски покупки жилья на ранних стадиях строительства ${ }^{1}$. Риски связаны с существующим механизмом долевого строительства, используемого организациями-застройщиками. В настоящее время в России их больше шести тысяч. В 80-90 \% строительства жилья ими используются деньги дольщиков по следующей схеме: собранные на конкретный дом средства направляются для достройку предыдущего проекта. Создаётся финансовая пирамида, рушащаяся при остановке притока денег. В итоге появляются брошенные и недостроенные дома, в которые дольщики вложили средства, но остались без квартир. По данным рабочей группы президиума генерального совета партии «Единая Россия» по защите прав вкладчиков и дольщиков, на 1 января 2017 г. в России насчитывалось 928 проблемных жилых объектов, а количество обманутых дольщиков составляло около 132 тыс. человек. По состоянию на 1 июля 2017 г., по данным Минстроя России, в 69 регионах страны официально насчитывается 785 проблемных объектов ${ }^{2}$. Для устранения негативной ситуации было принято решение об изменении механизма финансирования строительства жилья и повышении ответственности застройщиков.

Основные изменения в сфере долевого строительства. Проблема имеет давнюю историю. Ещё в 2004 г. был принят закон ФЗ-214 «Об участии в долевом строительстве многоквартирных домов и иных объектов недвижимости» ${ }^{3}$, запрещающий девелоперам брать деньги за квартиру до получения разрешительных документов на строительство; обязал их прописывать в договоре все сроки и неустойки за его неисполнение; регистрировать договор, чтобы исключить двойные продажи. Застройщи-

${ }^{1}$ URL: https://realty.newsru.com/article/26oct2017/dolshiki.

2 Петухова Л. Обездоленные инвесторы. Стоит ли вкладываться в недвижимость в преддверии отмены долевого строительства // РБК. № 193. URL: https://www.rbc.ru/newspaper/2017/11/10/59f 9acf59a794703d922a9c2.

${ }^{3}$ Об участии в долевом строительстве многоквартирных домов и иных объектов недвижимости и о внесении изменений в некоторые законодательные акты Российской Федерации [Электронный ресурс] : федер. закон от от 30 дек. 2004 г. № 214-ФЗ. // СПС «Консультант Плюс».

\section{Baikal Research Journal}

электронный научный журнал Байкальского государственного университета 
ки изобретали способы уклонения от запретов, а чиновники и депутаты пытались им противостоять, внося «косметические» поправки. Поскольку проблема не решалась, с 2015 г. начали принимать меры ${ }^{4}$, а кардинальные изменения определились в 2016 г. - достаточно жёсткие поправки к законам о долевом строительстве ${ }^{5}$.

С 1 июля 2017 г. вступил в силу Федеральный закон от 3 июля 2016 г. № 304-Ф3 «О внесении изменений в Федеральный закон «Об участии в долевом строительстве многоквартирных домов и иных объектов недвижимости и о внесении изменений в некоторые законодательные акты Российской Федерации» и отдельные законодательные акты Российской Федерации». Остальные поправки планируется внедрить с 1 января 2018 г. Изменения затрагивают два аспекта проблемы дольщиков: ужесточение контроля над строителями и поиск денег для компенсации пострадавшим гражданам. В перспективе планируется полный отказ от долевого участия при строительстве жилых домов, его должно заменить на проектное финансирование строек с привлечением банковских кредитов. Это означает, что привлечение частных инвестиций в строительство домов на ранней стадии станут невозможными. Президент Владимир Путин 5 ноября 2017 г. поручил правительству разработать план действий, который позволит в течение трех лет полностью отказаться от договоров долевого участия (ДДУ) при строительстве жилой недвижимости, что означает продажу на рынке только готовых квартир в уже построенных зданиях. Ситуация с обманутыми дольщиками станет невозможной, а у застройщика останется только два реальных источника финансирования строительства - кредит на весь срок строительства и собственные деньги. Ему придётся проходить жесткие банковские проверки, отчитываться перед кредиторами и раскрывать коммерческую информацию.

Также с 1 июля 2017 г. с целью усиления контроля над организациями-застройщиками установлены минимальные требования к их уставному капиталу. Если требования не выполняются, застройщики лишаются права заключать договоры участия в долевом строительстве. Кроме того вступают в силу:

- положение об обязательстве заключить договор поручительства, если размер уставного капитала застройщиков не соответствует новым требованиям;

- положение о Едином реестре застройщика;

- положение о привлечении долевых инвестиций через счета эскроу.

Величина уставного капитала организации-застройщика теперь будет зависеть от площади квартир и нежилых помещений в строящихся домах:

$-2,5$ млн рублей при площади не более 1,5 тыс. м $^{2}$ (минимальный показатель);

- 1,5 млрд р. - более 500 тыс. м² (максимальный).

Если капитал меньше требуемой величины, застройщик может подписать договор поручительства с другими компаниями для объединения своих финансовых ресурсов. Если же застройщик, капитал которого был недостаточным, не смог довести стройку до конца, его обязанности перед дольщиками должны выполнить поручители. Уставной капитал должен быть полностью оплачен в уставной фонд — в противном случае компания не будет иметь права привлекать деньги дольщиков.

${ }^{4} \mathrm{O}$ государственной регистрации недвижимости [Электронный ресурс] : федер. закон от 13 июля 2015 г. № 218-Ф3. // СПС «Консультант Плюс» .

${ }^{5}$ О внесении изменений в Федеральный закон «Об участии в долевом строительстве многоквартирных домов и иных объектов недвижимости и о внесении изменений в некоторые законодательные акты Российской Федерации» и отдельные законодательные акты Российской Федерации» [Электронный ресурс] : федер. закон от 03 июля 2016 г. № 304-ФЗ // СПС «Консультант Плюс». О защите прав граждан - участников долевого строительства. Постановление Правительства Российской Федерации от 7 декабря 2016 года № 1310. // Консультант Плюс. Версия Проф. О внесении изменений в Ж илищный кодекс РФ [Электронный ресурс] : федер. закон от 03 июля 2016 г. N 267 : (ред. от 28 дек. 2016) // СПС «Консультант Плюс».

\section{Baikal Research Journal}

электронный научный журнал Байкальского государственного университета 
Единый реестр застройщика уже действует. На его сайте представлена полная база данных об организациях, осуществляющих в РФ жилищное строительство по ДДУ, где указано название компаний-застройщиков, количество и площадь строящихся объектов, размеры уставного капитала, рейтинг компаний и бренды, под которыми они рекламирует свою деятельность.

Счёт эскроу открывается в банке для временного размещения средств граждан при заключении ими договора долевого участия в строительстве. Условием открытия является государственная регистрация ДДУ, а право на открытие эскроу-счетов по ДДУ получают только те кредитные учреждения, где можно размещать средства федеральной казны на банковских депозитах - специальное постановление правительства РФ (№ 498 от 27.04.2017). Их список ежеквартально обновляется на сайте Центробанка России. Застройщики получат доступ к средствам только после завершения работ, подписания акта о приёмке квартиры и представления его в банк, что по замыслу законодателя является гарантией завершения возведения жилья в срок.

Обеспечение обязательств застройщиков по договору участия в долевом строительстве возложено на колпенсационный фонд, начавший работать в конце октября 2017 г. Теперь все застройщики, продающие квартиры на стадии строительства, по закону должны перечислять в него $1,2 \%$ от цены каждого договора участия в долевом строительстве. Зарегистрировать ДДУ строительная компания сможет только после выплаты в компенсационный фонд. Функции фонда:

- контроль поступлений выплат от застройщиков;

- ведение дела о банкротстве строительной компании в качестве арбитражного управляющего;

- выплата возмещения дольщикам, если застройщик обанкротился;

- займы застройщикам, которые возьмут на себя обязательства по завершению стройки.

Создание компенсационного фонда, по мнению специалистов, является более әффективным способом защиты для участников строительства по сравнению со страхованием ответственности застройщика. В России практически отсутствуют случаи выплат дольщикам по недостроенным объектам, осуществлённые страховыми компаниями [1]. Те компенсационные фонды, которые существовали ранее и формировались в СРО, имеют множество проблем. На XIII Всероссийском съезде СРО в строительстве 11 апреля 2017 г. выяснилось, что меры правительства по обеспечению сохранности средств компенсационных фондов не уберегли их от потерь. Из 100 млрд р. средств компфондов половина так и не переведена на специальные счета в отобранных правительством банках. Примерно 10-15 млрд р. у СРО есть, но не размещены как положено, основная же часть денег безвозвратно потеряна в банках с отозванными лицензиями ${ }^{6}$. Средства СРО буквально тают на глазах: одно из объединений имело на счетах миллиарды, а к 1 декабря осталось с миллионами. При проверке выяснилось, что средства размещались в десятке коммерческих банков, и у всех в 2016 г. были отозваны лицензии. Законы о $\mathrm{CPO}$, принятые Государственной думой, оставляют огромное количество лазеек для недобросовестных организаторов, но не защищают ни потребителей, ни добросовестные организации ${ }^{7}$. Создание компенсационного фонда по новым правилам направлено на искоренение имеющихся недостатков.

6 Компенсационные фонды для защиты дольщиков наполовину пусты. большая часть средств потеряна в банках с отозванными лицензиями. URL: http://realty.irk.ru/analytics. php?id=17097\&action $=$ show\&.

7 Построили больше, но проблем хватает // Байкальские вести 2017. 31 янв. URL: http:// baikvesti.ru/new/important/built_more_but_enough_problems.

\section{Baikal Research Journal}

электронный научный журнал Байкальского государственного университета 
Комплекс выполненных и планируемых мер, рассмотренных нами, на первый взгляд, представляется логичным, но возникает закономерный вопрос: действительно ли этого будет достаточно для решения накопившихся проблем в отрасли строительства и ликвидации обманутых дольщиков. Сейчас реакция на принятые законы среди теоретиков и практиков неоднозначная.

Как оценивать произошедшие и будущие изменения в сфере долевого строительства. Формулировка решаемой проблемы в отрасли строительства практически не обсуждается, поскольку представляется очевидной и сводится к наличию обманутых дольщиков. Действительно, риски покупки жилья гражданами на ранних стадиях строительства велики, их отрицательные последствия катастрофичны для них. Но, на наш взгляд, она более масштабна и нуждается в уточнении, а затем в соотнесении с достаточностью предлагаемых для решения средств и возможными последствиями, тогда можно обоснованно ответить на поставленный выше вопрос. Для этого предлагается использование системо-мыследеятельностной методологии (СМД-методологии), адаптированной к поставленным целям настоящего исследования [2].

Методологи не только и не столько объясняют реальность, они разрабатывают средства для изменения ситуации. С позиций СМД-методологии, мышление всегда первично по отношению к знаниям и практике, т.е. к реальности: сначала должны быть развиты средства человеческого мышления, а потом уже предметные или объектные знания, которые всегда являются следствием метода и средств, развития мышления и гуманитарных технологий. Гуманитарные технологии не управляют людьми - они управляют правилами и рамками их общения и взаимоотношений. Мир мыслей и схем определяет мир вещей, он в представлениях методологов так же реален. Кроме того, конечный результат в методологической системе - вещь фактически невозможная: их главная цель - непрерывное развитие 8

В организационно-деятельностных играх, проводимых совместно методологами П. Г. Щедровицким и С. В. Поповым, а затем П. Г. Щедровицким, при большой разности их результатов выработана схема коллективного мышления, приводящая к выявлению и формулировке проблемы, последующей организации деятельности по её преодолению (рис. 1).

Работа по схеме предусматривает несколько этапов: первый начинается с анализа ситуации затруднения, движение идет сверху вниз. Затем определяются цели, достижение которых должно изменить ситуацию и снять затруднение. Для изменения ситуации необходимо определить и перепроектировать деятельность объектов (сил), вызвавших ситуацию затруднения. Результатом должно стать выявление проблемы или проблем, требующих решения. То есть в методологическом подходе постулируется, что проблема не лежит на поверхности, она может быть неочевидной, её легко упростить или перепутать со следствием, и соответственно предложить неверные решения, влекущие за собой непредвиденные новые затруднения. А при традиционном подходе считается, что проблема задана, и надо только найти способ её решения.

На втором этапе движение осуществляется в обратном направлении, идет проверка соответствия проблемы объектам, целям и ситуации затруднения. Если проблема сформулирована правильно, то ситуация затруднения в итоге должна быть снята. На втором этапе идет корректировка объектов и целей, уточняется ситуация. Если соответствие не достигнуто, то осуществляется третий этап. Процесс повторяется до тех пор, пока не будет достигнуто соответствие. Как правило, для снятия ситуации затруднения осуществляется 3-4 этапа.

${ }^{8}$ Щедровитяне: кто формировал мировоззрение Сергея Кириенко. Внутренней политикой России займутся методологи. // Carnegie.ru. 2016. 26 окт. URL: https://meduza.io/feature/2016/ 10/26/ schedrovityane-kto-formiroval-mirovozzrenie-sergeya-kirienko

\section{Baikal Research Journal}

электронный научный журнал Байкальского государственного университета 


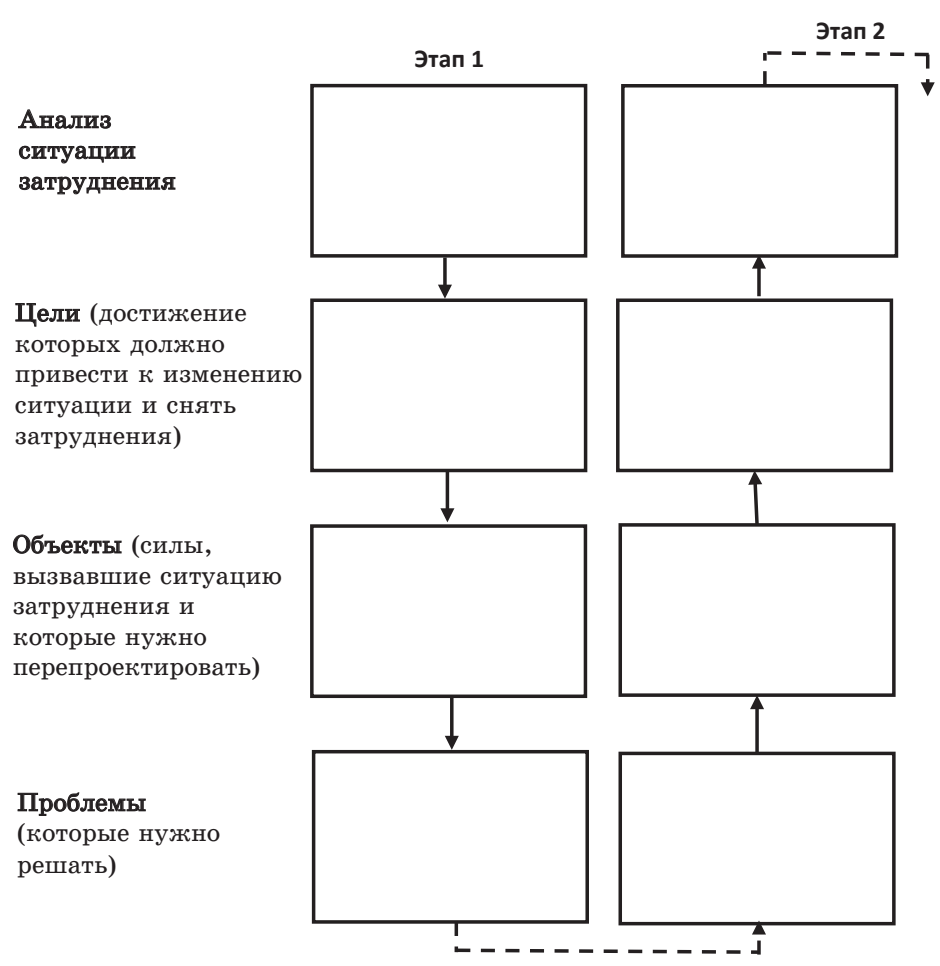

Рис. 1. Схема выявления проблем и оценки деятельности по их преодолению

Достоинством схемы является возможность перепроектирования деятельности объектов, вызвавших ситуацию затруднения. Коллективное обсуждение результатов по схеме позволяет проверить логику мышления и обеспечить непрерывное развитие. При традиционном подходе усилия направлены на изменение формы. Таким ярким примером является образование в России саморегулируемых строительных организаций (СРО) - создание формы не обеспечило эффективной деятельности.

На каждом этапе жизненного цикла отрасли и её организаций существуют свои проблемы. Их выявление позволяет своевременно разрабатывать средства для решения, не останавливая развитие [3; $4 ; 5]$.

Осуществление этапов схемы выявления проблем и оценки деятельности по их преодолению. Этап 1 - Анализ ситуации затруднения. Рост числа обманутых дольщиков, наличие недобросовестных застройщиков-инвесторов, проблемных объектов строительства - это только часть ситуации. Другие составляющие вызваны несовершенством общехозяйственных условий в стране, результатом которых является падение платёжеспособного спроса населения и сложное положение организаций-застройщиков. В итоге про то, что строительство так и не стало локомотивом экономического роста, и каковы причины этого, практически забыли [6].

По данным информационно-аналитического материала о состоянии делового климата в строительстве в III квартале 2017 г. и ожиданиях предпринимателей на IV квартал 2017 г., подготовленного Центром конъюнктурных исследований Института статистических исследований и экономики знаний Национального исследовательского университета «Высшая школа экономики», строительная от-

\section{Baikal Research Journal}


расль в целом продолжила свой стагнационный экономический «дрейф». Ограничение спроса на строительные услуги со стороны государства, корпоративного сектора и домашних хозяйств стало наиболее негативным фактором деятельности отрасли по рецессионно-стагнационному сценарию в течении последних трёх лет. Главный результирующий композитный индикатор исследования сезонно скорректированный Индекс предпринимательской уверенности (ИПУ) в строительстве - вырос относительно значения предшествующего квартала на 4 п.п., составив $(-16 \%)$ (рис. 2$)^{9}$.

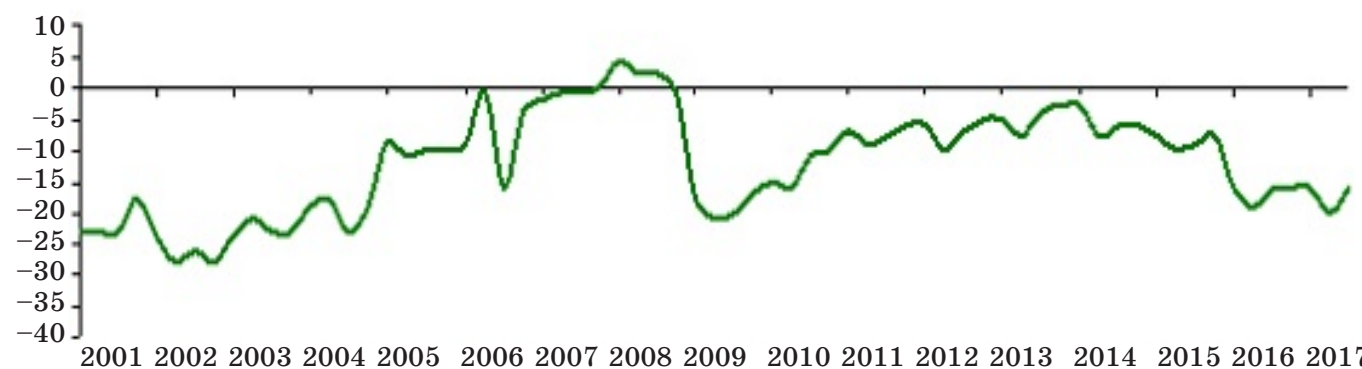

Рис. 2. Динамика индекса предпринимательской уверенности в строительстве (ИПУ) в процентах (Источник: ЦКИ ИСИЭЗ НИУ ВШЭ)

По тем же данным, в III квартале 2017 г. большинство показателей производственно-финансовой деятельности строительных организаций сохранили и продолжили накапливать негативную динамику. Усилилась тенденция сокращения обеспеченности строительных организаций собственными финансовыми средствами. Доля стройорганизаций, в которых произошло ослабление финансового потенциала, увеличилась по сравнению со II кварталом с 19 до 23 \%. Баланс оценки изменения показателя снизился на 6 п.п. и составил $(-16 \%)$. Возобновилась тенденция к сокращению обеспеченности строительных организаций кредитными и заемными финансовыми средствами. Балансовое значение индикатора, снизившись относительно предшествующего квартала на 3 п.п., вновь вернулось в отрицательную плоскость, составив $(-2 \%)$. На момент опроса средняя обеспеченность организаций отрасли финансированием составила 5 месяцев, что меньше показателя предыдущего квартала на 1 месяц. Наибольшая доля $(30 \%)$ предприятий была профинансирована на срок от 1 до 3 месяцев, 8 \% - более года. По оценке директора Центра конъюнктурных исследований Института статистических исследований и экономики знаний НИУ ВШЭ Г. Остапковича, отрасль находится в зоне неблагоприятного делового климата. Основная проблема отрасли — это слабый совокупный спрос на строительные услуги со стороны трех основных заказчиков - государства, корпоративного сектора и населения ${ }^{10}$.

Не менее актуальной составляющей ситуации затруднения является необеспеченность безопасности создаваемых объектов недвижимости, возводимых на контрактной основе. Федеральный закон от 05.04.2013 г. № 44-ФЗ «О контрактной системе» определил инструменты управления стоимостью, нацеленные на минимизацию затрат, но не на обеспечение безопасности создаваемых объектов недвижимости. В процесс реализации проектов внедрён дополнительный (проме-

${ }^{9}$ Обзор состояния делового климата в строительной отрасли России в III квартале 2017 года. URL: https://erzrf.ru/publikacii/obzor-sostoyaniya-delovogo-klimata-v-stroitelnoy-otrasli-rossii-v-iiikvartale-2017-goda.

10 Там же.

\section{Baikal Research Journal}


жуточный) этап подрядных торгов, в результате стоимость объекта формируется производственными факторами и зависит от рыночной конъюнктуры - конкурентной борьбы между участниками торгов. Данный закон не исключает риск занижения цены проекта, вынуждающего победителя торгов экономить на затратах в период исполнения контракта, но не устраняет его. Это приводит к изменению проектных решений, снижению качества строительства, упрощению требований к характеристикам строительных материалов, использованию менее квалифицированных рабочих. Результатом является снижение долговечности строительных конструкций и объектов в целом, приводящее к их обрушению в период эксплуатации объектов недвижимости.

Л. В. Брезгина в своей диссертационной работе провела уникальное исследование причин обрушения зданий и сооружений за периоды, когда существовали идеальные условия формирования стоимости (при отсутствии рынка), определяемые только производственными факторами (1981-1992 гг.), а также периоды введения в действие законов, создающих рыночные условия формирования стоимости (1993-2015 гг.) [7, с. 11-14].

Для определения динамики ею была собрана информация по г. Москве, Московской области, г. Перми и Пермскому краю об обрушениях, связанных с низким качеством строительства, используемых материалов и проектирования. Были использованы разные источники, действовавшие в разные периоды времени: служба государственной статистики РФ, данные Госстроя СССР, Госархс[тройнадзора РСФСР и др. (рис. 3).

На формирование стоимости влияют производственные факторы
На формирование стоимости влияют производственные, рыночные и поведенческие факторы

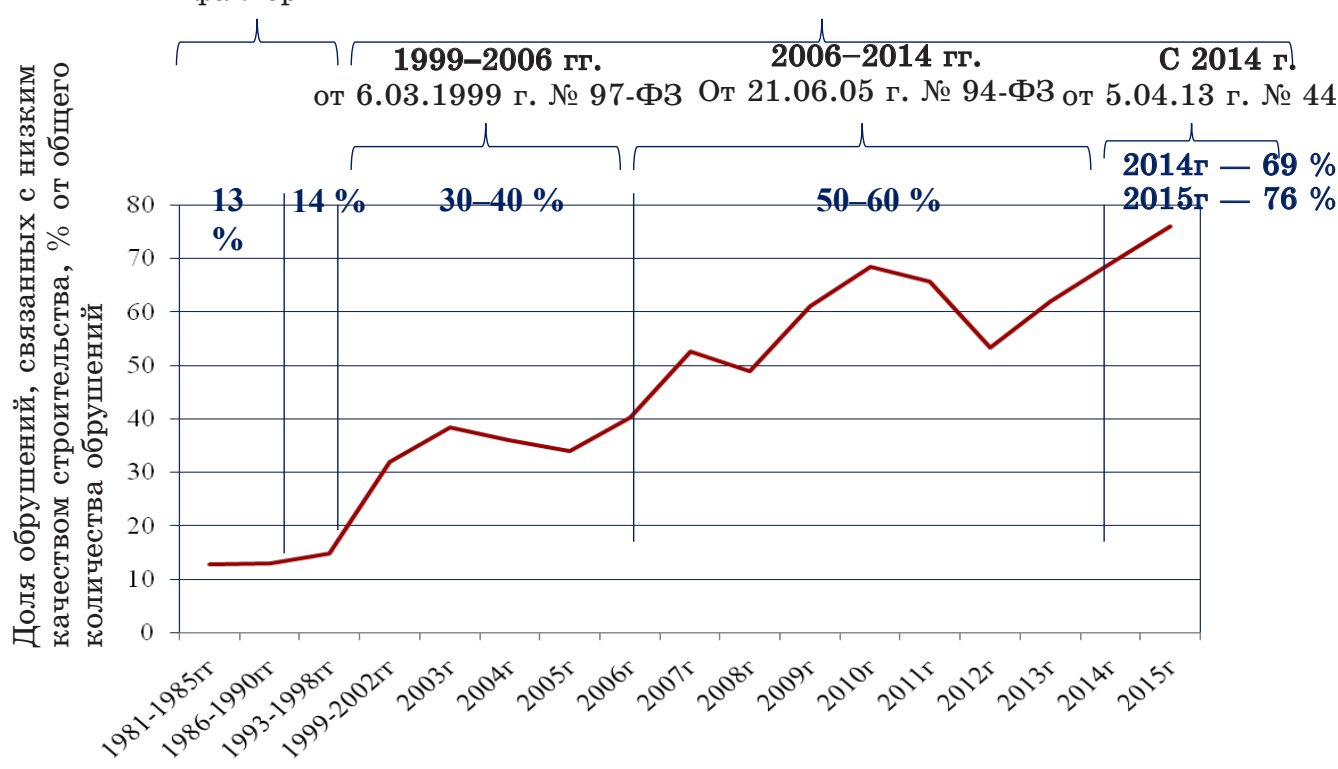

Рис. 3. Диналика обрушений, связанных с низкил качеством строительства (источник [7, с. 12])

До 1992 г. в России использовался принцип планового размещения заказов на продукцию (доля обрушения зданий и сооружений, вызванных с

\section{Baikal Research Journal}


низким качеством строительства, составляла в среднем 13 \%). В 1992 г. был провозглашен принцип конкурсного определения исполнителей государственного заказа. Доля обрушения зданий и сооружений составила ежегодно в среднем $14 \%$. Формирование современной системы подрядных торгов началось с 1999 г. Вначале был принят закон от 6 мая 1999 г. № 97-ФЗ «О конкурсах на размещение заказов». Он регулировал отношения между организатором и участниками конкурсных процедур подрядных торгов. В период его действия обрушения зданий и сооружений из-за низкого качества строительства составляла ежегодно в среднем $30-40 \%$.

Затем был принят закон от 21 июля 2005 г. № 94-Ф3 «О размещении заказов на поставки товаров», расширивший способы размещения заказов - конкурсы, аукционы, запрос котировок. В период его действия обрушения зданий и сооружений увеличились до 50-60\%. Действующий закон № 44-ФЗ «О контрактной системе» от 5 апреля 2013 г. направлен на предотвращение коррупции и злоупотреблений в планировании и определение поставщиков. Закон установил принципы добросовестной ценовой и неценовой конкуренции, обязательность обоснования начальной (максимальной) цены контракта и методы ее определения. $\mathrm{C}$ начала его действия обрушения зданий и сооружений из-за низкого качества строительства увеличилась в 2014 г. до $69 \%$, а в 2015 г. - до 76 \% [7, с. 11-14].

Поведение застройщиков при строительстве детских садов, школ, жилых домов и других объектов это наглядно иллюстрируют. Например, на торгах победителем стала организация, предложившая наименьшую цену объекта. Возведенный объект после зимы стал разрушаться, пошли трещины в стенах. Начались судебные разбирательства. Выяснилось, что из-за снижения цены на торгах заказчик, чтобы уложиться в лимит, вынужден был изменить материал стен, кирпич был заменен на легкобетонные блоки, приведшие к разрушению здания.

Уточнение минимально допустимой цены проекта может происходить не только на подрядных торгах, но и на этапе проектирования. Заказчик может в техническом задании проектной организации включить пункт о проработке варианта снижения цены контракта. Но это увеличит затраты заказчика на разработку проектной документации. Крупному заказчику это по силам, остальные будут сами определять границу снижения. Начальная (максимальная) цена контракта, определяемая нормативным подходом (приказ Минэкономразвития РФ от 02.10.2013 г. № 567) учитывает идеальные условия формирования стоимости за счёт производственных факторов и обеспечения безопасности, надежности и качества объектов недвижимости строгим соблюдением строительных норм. На этапе подрядных торгов цена проекта снижается без технико-экономического обоснования, в ходе конкурентной борьбы между участниками торгов и зависит от их индивидуально-рыночных мотиваций, рациональности или иррациональности поведения со всеми вытекающими рисками. Вместо дорогих и надежных материалов и конструкций используются низкокачественные и деш $\square$ вые, нарушаются технологии утепления стен-сэндвичей и создания кровли, приобретаются устаревшие модели лифтов и т.п.

Л. В. Брезгина предлагает устанавливать предел снижения цены, чтобы определить минимально необходимые затраты, обеспечивающие требуемое качество строительства. Но это возможно лишь при использовании механизма государственного контракта, доля которого в общем объёме строительства в стране составляет примерно 60 \%, когда при всём несовершенстве законодательства рациональность цены хоть как-то рассматривается. Если же объект возводится по прямому договору с заказчиком без проведения торгов, то подрядной организации могут быть навязаны кабальные невыполнимые условия. Этим пользуются

\section{Baikal Research Journal}

электронный научный журнал Байкальского государственного университета 
заказчики, работающие с субъектами малого и среднего предпринимательства в строительстве, особенно находящимися в тяжёлых финансовых условиях. Чтобы получить заказ, организация-застройщик готова на любые условия заказчика, включая цену «отката». Затем начинается оптимизация затрат на материалы и конструкции, приводящая к потере качества и обрушениям. Пока заказы поступают непрерывно (работает принцип пирамиды), организации-застройщики както выживают. В условиях кризиса неминуемо банкротство и массовое появление проблемных объектов строительства. Это подтверждается и официальной статистикой: с 2014 г. небольшие компании, которые продавали по 1-2 объекта, как и все столкнулись со снижением спроса, что увеличило просроченную задолженность, усложнило финансирование со стороны банков, нарушило инвестиционный процесс и усилило банкротство мелких компаний (рис. 4).

\section{Kак живуm cmpoumenu}

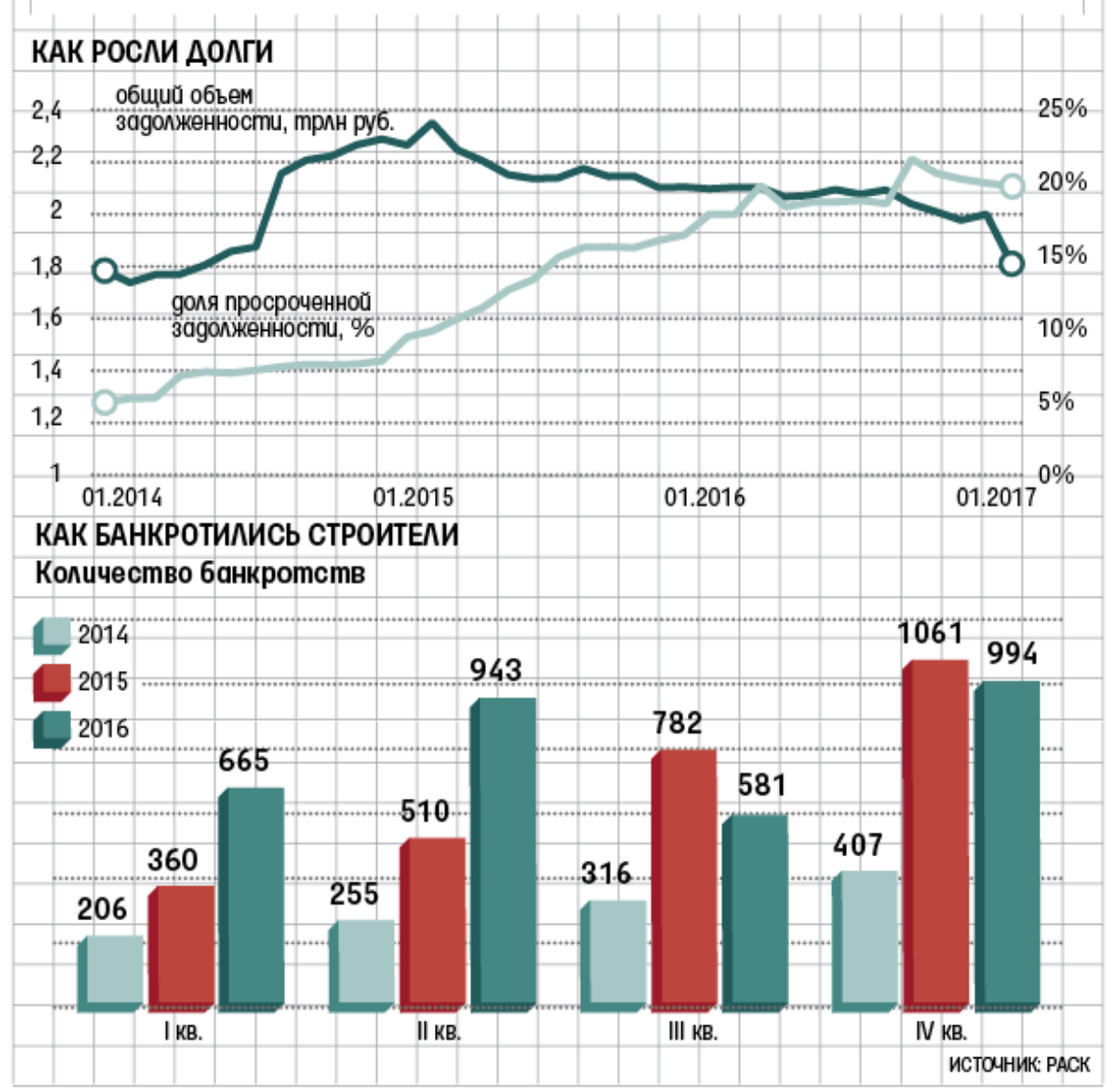

Рис. 4. Диналика долгов и банкротства строительных организаций

(URL: https://www.vedomosti.ru/realty/articles/2017/04/04/684003-krizis-usugublyaetsya)

\section{Baikal Research Journal}

электронный научный журнал Байкальского государственного университета 
Доходность строительной отрасли, по данным Росстата, составляет в среднем $5,2 \%$. Рост возможен при условии достижения доходности «инфляция плюс $1 \%$ ». В 2016 г. официальная инфляция была 5,4 \%. То есть, сколько бы ни вложили в отрасль, заработать застройщики выше инфляции не смогут. В результате с рынка уходят компании, а кредитование сектора сокращается. По данным Рейтингового Агентства Строительного Комплекса (РАСК) в 2016 г. банкротами были признаны 3183 компании, что выше аналогичного показателя 2015 г. на 17,3 \% (2713 банкротов). Из организаций-банкротов 66 \% проработали на строительном рынке не менее семи лет, 32 \% компаний - от трех до семи лет, и лишь $2 \%$ - молодые компании. В результате с сентября 2014 г. доля строительной отрасли в кредитном портфеле банков непрерывно снижается - с 9,7 до $7,4 \%$. Доля просроченной задолженности по рублевым кредитам составила 24,7 \% - каждый четвертый кредитный рубль является проблемным. По итогам 2015 г. кредитов было выдано на $32,5 \%$ меньше, чем в 2014 г. В 2016 г. наблюдается увеличение всего на 6,4 \%. Практически половину всего портфеля кредитов формирует Москва $(49,7$ \%), следом идет Санкт-Петербург $(8,1 \%)[8]$.

Можно утверждать, что предполагаемые меры по отказу от долевого строительства приведут к дальнейшему ухудшению ситуации. У застройщиков не хватает собственных финансовых ресурсов, но все принятые решения направлены на дальнейшее отстранение их от денег. Основная причина наличия обманутых дольщиков - это следствие обрушения финансовых пирамид, выстраиваемых организациями-застройщиками из-за отсутствия собственных средств и дорогого банковского кредита. Проблема является системной и требует адекватно решения. Поэтому постановка цели создания действенного механизма защиты прав граждан, минимизирующего риски покупки жилья на ранних стадиях строительства, без учёта общехозяйственной ситуации в стране и состояния отрасли строительства, ограничивает определение объектов, которые нужно перепроектировать для снятия затруднения, и концентрирует внимание только на части проблемы. Необходим проект системного совершенствования деятельности всех сторон, участвующих в процессе создания объектов недвижимости и влияющих на него государства и контролирующих застройщиков инстанций, Центрального Банка и коммерческих кредитных организаций, страховщиков и поставщиков ресурсов. До тех пор, пока организации-застройщики будут получать кредитные ресурсы под 13-20\% годовых ${ }^{11}$ (а средние мелкие - под $25 \%$ и выше), переход на проектное финансирование является нереальным. Согласно нововведениям, проектное финансирование осуществляется при наличии полной проектной документации, разрешения на строительство и не менее $30 \%$ средств, вложенных в осваиваемую площадку. Эти условия выполнить практически невозможно.

Ситуация в отрасли (общий объем задолженности, доля просроченной задолженности, количество банкротств) имеют негативный тренд. Проектное финансирование его усилит, на рынке останутся только крупные застройщики, действующие как группы компаний, имеющие возможности беспроцентно кредитовать входящие в них организации за счёт собственных средств, аккумулируемых в холдинге. Наши расчёта показали, что процентной ставке до $5 \%$ годовых многие затруднения в отрасли снимаются автоматически [9]. По мнению специалистов, ужесточение требований к участникам долевого строительства приведёт к уменьше-

11 Построить среду доверия // Строительная газета. 2017. 4 авг. URL: https://www.stroygaz.ru/ search $/$ ? $=\%$ D0 $\%$ 9F $\%$ D0 $\%$ BE $\%$ D1 $\% 81 \%$ D1 $\% 82 \%$ D1 $\% 80 \%$ D0 $\%$ BE $\%$ D0 $\%$ B $8 \%$ D $1 \% 82 \%$ D1 $\%$ 8C+\% D1 $\% 81 \%$ D1 $\% 80 \%$ D0 $\%$ B5 $\%$ D0 $\%$ B4 $\%$ D1 $\% ~ 83+\%$ D0 $\%$ B4 $\%$ D0 $\%$ BE $\%$ D0 $\%$ B2 $\%$ D0 $\%$ B5 $\%$ D $1 \% 80 \%$ D0 $\% \mathrm{~B} 8 \% \mathrm{D} 1 \% 8 \mathrm{~F}$.

\section{Baikal Research Journal}

электронный научный журнал Байкальского государственного университета 
нию количества действующих на рынке субъектов предпринимательства, особенно малых и средних предприятий, что грозит монополизацией рынка $[10 ; 11]$. Полностью соответствовать всем предъявляемым требованиям может только крупная государственная корпорация, специально созданная для реализации масштабных проектов. Кроме того, вводимые изменения затронут тех застройщиков, которые заключили ДДУ по прежним правилам, поэтому помочь имеющимся обманутым дольщикам и тем, кто покупает жилье в нынешних проектах, поправки не смогут.

Предлагаемая формулировка проблемы. Нами предлагается следующая постановка проблемы: отсутствие условий для роста эффективности в отрасли строительства, нерациональность кредитно-денежной политики ЦБ, провоцирующая экономический кризис в стране и снижение платежеспособности населения. Будущее строительства жилья в большей степени зависит от состояния экономики России, в меньшей - от изменения законодательства.

Известно, что рынок коммерческого жилищного строительства и иных объектов недвижимости может развиваться при благоприятных экономических условиях. Ужесточение законодательства принято в момент упадка рынка. Сегодня действует механизм страхования, составляющий порядка 1,4 \% от стоимости квартиры, параллельно вводится компенсационный фонд - 1,2 \% от стоимости квартиры, что ведёт к росту цен. По оценкам практиков, даже $1 \%$ роста стоимости квартиры уменьшает прибыль организации на $10 \%$, снижает рентабельность в строительном бизнесе, усугубляя и без того сложную ситуацию. За последние два года в Иркутской области стоимость квадратного метра по государственным программам увеличена на $1,6 \%$, а реальная себестоимость возросла на $25-30 \%$ из-за удорожания строительных материалов и оборудования - арматуры, цемента, импортных лифтов и пр. ${ }^{12}$ Результатом является экономия на качестве. На увеличение стоимости жилья влияет отсутствие инвестиций в инфраструктуру. Например, в Иркутске за последние 10 лет ни один застройщик не получил участок с подведенными сетями. Ресурсоснабжающие организации создают множество проблем при подключении к сетям. Принимаемые меры фактически не приводят к перепроектированию деятельности объектов, вызвавших ситуацию затруднения в отрасли строительства, поскольку направлены на изменение формы.

Наличие обманутых дольщиков в России не характерно для состоятельных граждан, они покупают готовое элитное жильё за наличные деньги. Их рассматриваемая в статье проблема не волнует. Малообеспеченное население вообще не имеет возможности решать свои жилищные проблемы. Обманутыми дольщиками чаще всего становится представители интеллигенции со средним достатком, не имеющие другой возможности улучшить свои жилищные условия и не знакомые с отечественными процедурами негативного предпринимательства. Поэтому неясно, кому пригодится совет Министра финансов России А. Силуанова покупать готовое жилье, а не вкладываться в долевое строительство с непонятными последствиями ${ }^{13}$. Главный итог возможного перехода к проектному финансированию рост стоимости жилья, поскольку по займам банков в отличие от средств дольщиков нужно платить процент. Если сейчас застройщик может расплатиться с банком до окончания строительства, то согласно новым правилам придется брать кредит на весь срок реализации, и рассчитываться только после ввода здания в эксплуатацию. На рынке останется преимущественно готовое жилье, которое на 20-30 \% дороже строящихся аналогов [12].

12 Пшенко О. Строители теряют прибыли и заворачивают проекты // Областная. 2017. 8 марта. URL: http://www.ogirk.ru/news/2017-03-08/stroiteli-teryayut-pribyli-i-zavorachivayut-proekty.html

${ }^{13}$ Силуанов посоветовал гражданам не вкладываться в долевое строительство // Ведомости. URL: https://www.vedomosti.ru/realty/news/2017/10/27/739680-siluanov-posovetoval

\section{Baikal Research Journal}

электронный научный журнал Байкальского государственного университета 
Осуществление проверки рациональности предложенной нами формулировки проблемы осуществлено согласно этапу 2 по схеме выявления проблем и оценки деятельности по их преодолению (см. рис. 1). На наш взгляд, постановка проблемы разумна и ее решение действительно снимет затруднения на рынке строительства жилья. В перспективе переходить к цивилизованным формам банковского финансирования строительства необходимо, но возложить всю ответственность за результаты на застройщиков без изменения условий хозяйствования в стране и отрасли невозможно и экономически опасно.

В сложившихся условиях актуально развитие альтернативных вариантов строительства жилья - использование инструментов прямого финансирования (эмиссия жилищных сертификатов) и косвенного (эмиссия однотраншевых ипотечных жилищных облигаций). Первые предполагают финансирование строительства напрямую с участием сбережений населения, вторые финансируют жилищное строительство косвенно - через банковские ипотечные кредиты [13]. Также необходимо вернуться к осмыслению возможностей немецкого опыта создания стройсберкасс, так и не использованного в России [6].

Как финансируется строительство жилья за рубежом. В странах с развитой системой банковского жилищного финансирования долевое строительство применяется только при строительстве элитного жилья, поскольку найти покупателей на дорогую недвижимость трудно, её строят под заказ. Более распространенной в мире практикой является схема массового жилищного строительства, при которой застройщики на какую-то часть (до 50 \%), заключают предварительные договоры. По ним регулируется размер задатка, как правило, в 10-15\%. Он необходим застройщикам для гарантии спроса хотя бы на 50 \% квартир. Затем они привлекают банковское проектное финансирование - кредитные линии на строительство и возводят дом. После завершения строительства покупатели платят оставшиеся 85-90\% от стоимости своих квартир, и остальное жильё распродаётся на рынке.

Для инвестиций в доступное жильё в США после экономического кризиса 2008 г. предусмотрен жилищный кредит «Доллар-в-доллар» (LIHTC - налоговый кредит на жилищное строительство для людей с низким доходом), финансируемый федеральным правительством, но регулируемый управлением жилищного хозяйства штата, что позволяет учесть местную специфику. Кредит стимулирует использование частного капитала малообеспеченных граждан за счёт налоговых льгот [14].

К деятельности по новым правилам в России пока не готовы все стороны, участвующие в строительстве, должен быть переходный период по созданию условий для экономики в целом и в отрасли. Застройщики не готовы, потому что для них это будет более дорогое финансирование, кроме того, им придётся приводить в порядок свою внутреннюю финансовую систему, чтобы она стала понятна и прозрачна банкам. Банки не готовы, потому что практика проектного банковского финансирования пока очень ограничена. Банки не очень хорошо понимают риски подобного кредитования, у них недостаточно компентенций и специалистов, которые могут контролировать процесс строительства, читать проектную документацию и следить за соблюдением её требованием, обеспечением технологий при строительстве объекта и пр. А потенциальные покупатели жилья не готовы, поскольку боятся, что оно окажется для них дороже. Президент Фонда «Институт экономики города» Н. Б. Косарева предлагает для стимулирования переходного

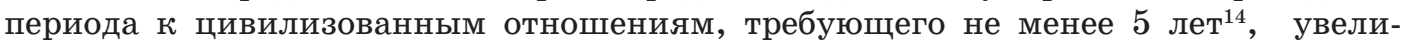

${ }^{14}$ Надежда Косарева: Для полного перехода от долевого строительства жилья к проектному финансQированию потребуется не менее пяти лет. URL: https://erzrf.ru/news/nadezhda-kosareva-dlya-polnogoperekhoda-ot-dolevogo-stroitelstva-zhilya-k-proyektnomu-finansirovaniyu-potrebuyetsya-ne-meneye-pyatilet?search= $\%$ D0 $\%$ 9A $\%$ D0 $\%$ BE $\%$ D1 $\% 81 \%$ D0 $\%$ B0 $\%$ D1 $\% 80 \%$ D0 $\%$ B5 $\%$ D0 $\%$ B2 $\%$ D0 $\%$ B0

\section{Baikal Research Journal}

электронный научный журнал Байкальского государственного университета 
чить размер страхования для эскроу-счетов с 1,4 млн рублей до полного размера, поскольку банковский риск не нулевой. По её мнению, поставлена сложная институциональная задача, требующая очень многих мер, причем не только непосредственно связанных с финансированием: новых технологий, развития конкуренции, повышения качества жилищного строительства, и так далее. Здесь очень много аспектов [15].

Фактически, Н. Б. Косарева подтверждает системный характер проблемы и говорит о необходимости создания общехозяйственных и отраслевых предпосылок для её решения в течение переходного периода, изменении институционального устройства рынка. Это очень сложная задача, решение которой пока не рассматривается.

\section{Список использованной литературы}

1. Кучерова О. Обездоленные дольщики [Электронный ресурс] / О. Кучерова // Banki.ru. 2017. - 27 февр. - Режим доступа: http://www.banki.ru/news/daytheme/?id=9561832

2. Светник Т. В. Методология анализа российских проблем отрасли строительства / T. В. Светник // Евроазиатское сотрудничество: гуманитарные аспекты : материалы Междунар. науч.-практ. конф., Иркутск, 14-15 сент. 2017 г. / под ред. А. П. Суходолова. Иркутск : Изд-во БГУ, 2017. - С. 403-410.

3. Grushina O. The housing problem in the light of market imperfections theory / O. Grushina, G. Khomkalov // Journal of Applied Economic Sciences. - 2016. - Vol. 11, iss. 3. - P. 501-511.

4. Светник Т. В. Методология исследования деятельностных возможностей строительной организации / Т. В. Светник // Механизм деятельности хозяйствующих организаций в рыночных условиях : материалы междунар. науч.-практ. конф., 21 мая 2009 г. - Иркутск : Изд-во БГУЭП, 2009. - С. 123-128.

5. Светник Т. В. Предпринимательский механизм управления продолжительностью жилищного инвестиционно-строительного цикла в городе / Т. В. Светник, И. Б. Королева. Иркутск : Изд-во БГУЭП, 2012. - 163 с.

6. Светник Т. В. Трансформация отрасли строительства в действенный локомотив экономического роста / Т. В. Светник // Вестник Иркутского государственного технического университета. - 2014. - № 12 (95). - С. 336-342.

7. Брезгина Л. В. Механизм управления стоимостью инвестиционно-строительных проектов на этапе проведения подрядных торгов региона : автореф. дис. ... канд. экон. наук : 08.00.05 / Л. В. Брезгина. - Екатеринбург, 2017. - 24 с.

8. Ляув Б. Кризис в строительной отрасли усугубляется [Электронный ресурс] / Б. Ляув // Ведомости. - 2017. - 4 апр. - Режим доступа: https://www.vedomosti.ru/ realty/articles/2017/04/04/684003-krizis-usugublyaetsya

9. Светник Т. В. Система долевого строительства и оценка механизмов ее замещения / Т. В. Светник, В. С. Вахнович // Известия Байкальского государственного университета, 2016. — T. 26, № 6. - C. 907-918. — DOI: 10.17150/2500-2759.2016.26(6).907-918.

10. Ручкина Г. Ф. Положение субъектов малого и среднего предпринимательства на рынке долевого строительства в свете изменений законодательства / Г. Ф. Ручкина, А. Г. Григорян // Имущественные отношения в Российской Федерации. — 2017. — № 7. — C. $18-26$.

11. Кирсанов А. Р. Законодательство о долевом строительстве: прошлое, настоящее и будущее / А. Р. Кирсанов // Имущественные отношения в Российской Федерации. 2017. - № 6. - С. 64-74.

12. Филатов А. Путин велел полностью отказаться от долевого строительства через три года [Электронный ресурс] / А. Филатов, Б. Ляув, А. Дидковская // Ведомости. - 2017. 8 нояб. - Режим доступа: https: //www.vedomosti.ru/realty/articles/2017/11/08/740859otkazatsya-dolevogo-stroitelstva.

13. Кубасова Т. И. Изменение приоритетов государственной поддержки финансирования программ в области жилищной политики / Т. И. Кубасова, Л. В. Каверзина // Известия

\section{Baikal Research Journal}

электронный научный журнал Байкальского государственного университета 
Байкальского государственного университета. — 2016. - Т. 26, № 6. - С. 947-954. DOI: 10.17150/2500-2759.2016.26(6).947-954.

14. Nevins F. How to Get Funding for a Low-Income Housing Development [Electronic resource] / F. Nevins // Marks Thomas. - 2015. - Mode of access: http://marks-thomas. com/2015/05/how-to-get-funding-for-a-low-income-housing-development/

15. Косарева Н. Б. Дальше - без дольщиков [Электронный ресурс] / Н. Б. Косарева // Полит.ру. - 2017. -

\section{References}

1. Kucherova O. Dispossessed interest-holders. Banki.ru. Available at: http://www.banki. $\mathrm{ru} /$ news/daytheme/?id=9561832 (In Russian).

2. Svetnik T. V. Analysis methodology for Russian problems in construction industry. In Sukhodolov A. P. (ed.). Evroaziatskoe sotrudnichestvo: gumanitarnye aspekty. Materialy mezhdunarodnoi nauchno-prakticheskoi konferentsii [Eurasian cooperation. Materials of International Scientific and Practical Conference. Irkutsk, September 14-15, 2017]. Irkutsk, Baikal State University Publ., 2017, pp. 403-410. (In Russian).

3. Grushina O., Khomkalov G. The housing problem in the light of market imperfections theory. Journal of Applied Economic Sciences, 2016, vol. 11, iss. 3, pp. 501-511.

4. Svetnik T. V. Research methodology for activity possibilities of building institutions. Mekhanizm deyatel'nosti khozyaistvuyushchikh organizatsii $v$ rynochnykh usloviyakh: Materialy mezhdunarodnoi nauchno-prakticheskoi konferentsii [Mechanism of economic organization activity in the market economy environment. Materials of International Scientific and Practical Conference, May 21, 2009]. Irkutsk, Baikal State University of Economics and Law Publ., 2009, pp. 123-128. (In Russian).

5. Svetnik T. V., Koroleva I. B. Predprinimatel'skii mekhanizm upravleniya prodolzhitel'nost'yu zhilishchnogo investitsionno-stroitel'nogo tsikla $v$ gorode [Entrepreneurial mechanism of managing the duration of housing investment and construction cycle in the city]. Irkutsk, Baikal State University of Economics and Law Publ., 2012. 163 p.

6. Svetnik T.V. Construction industry transformation into an efficient engine of economic growth Vestnik Irkutskogo gosudarstvennogo tehnicheskogo universiteta = Proceedings of Irkutsk State Technical University, 2014, no. 12 (95), pp. 336-342. (In Russian).

7. Brezgina L. V. Mekhanizm upravleniya stoimost'yu investitsionno-stroitel'nykh proektov na etape provedeniya podryadnykh torgov Regiona Avtoref Kand. Diss [Mechanism of managing the cost of investment and construction projects at the stage of regional contract tendering. Cand. Diss. Thesis]. Ekaterinburg, 2017. 24 p.

8. Lyauv B. Crisis in the construction industry escalates. Vedomosti. Available at: https:// www.vedomosti.ru/realty/articles/ 2017/04/04/684003-krizis-usugublyaetsya (In Russian).

9. Svetnik T.V., Vakhnovich V.S. The shared construction system and evaluation of mechanisms for its replacement. Izvestiya Baikal'skogo gosudarstvennogo universiteta $=$ Bulletin of Baikal State University, 2016, vol. 26, no. 6, pp. 907-918. DOI: 10.17150/25002759.2016.26(6).907-918. (In Russian).

10. Ruchkina G. F., Grigoryan A. G. Status of the small and medium-sized business entities in the light of changes legislation Imushchestvennye otnosheniya $v$ Rossiiskoi Federatsii= Property Relations in the Russian Federation, 2017, no. 7, pp. 18-26. (In Russian).

11. Kirsanov A. R. legislation of shared construction: past, present and future. Imushchestvennye otnosheniya $v$ Rossiiskoi Federatsii = Property Relations in the Russian Federation, 2017, no. 6, pp. 64-74. (In Russian).

12. Filatov A., Lyauv B., Didkovskaya A. Putin has ordered to refuse completely the shared construction in three years. Vedomosti. Available at: https: //www.vedomosti.ru/ realty/articles/2017/11/08/740859-otkazatsya-dolevogo-stroitelstva. (In Russian).

13. Kubasova T. I., Kaverzina L. A. Changing priorities in state financial support for housing policy programs. Izvestiya Baykal'skogo gosudarstvennogo universiteta = Bulletin of Baikal State University, 2016, vol. 26, no. 6, pp. 947-954. DOI: 10.17150/25002759.2016.26(6).947-954. (In Russian).

\section{Baikal Research Journal}


14. Nevins F. How to Get Funding for a Low - Income Housing Development. Marks Thomas, 2015. Available at: http://marks-thomas.com/2015/05/how-to-get-funding-for-alow-income-housing-development/

15. Kosareva N. B. To go further but without interest-holders. Polit.ru. Available at: http://polit.ru/article/2017/10/27/building/ (In Russian).

\section{Информация об авторе}

Светник Талара Васильевна - доктор экономических наук, профессор, кафедра экономики предприятия и предпринимательской деятельности, Байкальский государственный университет, 664003, г. Иркутск, ул. Ленина, 11, e-mail: svetnikt@mail.ru.

\section{Author}

Tamara V. Svetnik - Doctor habil. in Economics, Professor, Chair of Enterprise Economy and Entrepreneurship, Baikal State University, 11 Lenin St., 664003, Irkutsk; e-mail: svetnikt@mail.ru.

\section{Для цитирования}

Светник Т. В. Системный характер проблемы обманутых дольщиков в России / T. В. Светник // Baikal Research Journal. - 2017. — T. 8, № 4. — DOI : 10.17150/2411$\underline{6262.2017 .8(4)} .26$.

\section{For Citation}

Svetnik T. V. Systemic nature of the hoodwinked investors' problem in Russia. Baikal Research Journal, 2017, vol. 8, no. 4. DOI: 10.17150/2411-6262.2017.8(4).26. (In Russian).

\section{Baikal Research Journal}

